\title{
Stability-Indicating RP-HPLC Method for the Determination of Valaciclovir Hydrochloride in Bulk and Pharmaceutical Dosage Forms
}

\author{
DILLIP KUMAR SAHOO ${ }^{* 1}$ and PRAFULLA KUMAR SAHU ${ }^{2}$
}

${ }^{1}$ Department of Pharmaceutical Analysis, Avanthi Institute of Pharmaceutical Sciences, Cherukupally, Bhogapuram, Vizianagaram, Andhra Pradesh-531162, India

${ }^{2}$ Department of Pharmaceutical Analysis, Raghu College of Pharmacy, Dakamarri, Bheemunipatnam, Visakhapatnam, Andhra Pradesh-531162, India

sahoo4@rediffmail.com

Received 3 September 2013 / Accepted 6 October 2013

\begin{abstract}
A stability indicating reverse-phase HPLC method was developed for the determination of valaciclovir hydrochloride present in bulk and pharmaceutical dosage forms. The quantification was carried out using hypersil, ODS $\mathrm{C}_{18}(250 \times 4.6 \mathrm{~mm}$ i.d., packed with $5 \mu$ particle size $)$ in an isocratic mode column with mobile phase comprising acetonitrile: phosphate buffer $(\mathrm{pH}-3.6)$ in the ratio of 50:50 $(\% \mathrm{v} / \mathrm{v})$. The flow rate was at $0.8 \mathrm{~mL} / \mathrm{min}$ and detection was carried out at $252 \mathrm{~nm}$. The retention time was $2.850 \mathrm{~min}$ for valaciclovir hydrochloride and the method produced linear response in the concentration range of 0.5 to $200 \mu \mathrm{g} / \mathrm{mL}\left(\mathrm{R}^{2} \sim 0.9999\right)$. The recovery studies were also carried out and percent relative standard deviation from reproducibility was below $2 \%$. The limit of detection and limit of quantification for this method were $0.110 \mu \mathrm{g} / \mathrm{mL}$ and $0.363 \mu \mathrm{g} / \mathrm{mL}$, respectively. The proposed method was statistically evaluated and can be applied for routine quality control analysis of valaciclovir hydrochloride in Pharmaceutical dosage form.
\end{abstract}

Keywords: Valaciclovir, Stability indicating, RPHPLC

\section{Introduction}

Valaciclovir or valaciclovir is an antiviral drug used in the management of herpes simplex and herpes zoster (shingles). It is a prodrug, being converted in vivo to aciclovir. Many analytical methods are developed in order to determine valaciclovir in bulk and tablet dosage forms. Spectrophotometric ${ }^{1-2}$ methods were developed for the determination of valaciclovir in bulk and pharmaceutical dosage forms. RPHPLC methods were reported for estimation of valaciclovir in presence of degradation products ${ }^{3}$, to obtain degradation kinetics data ${ }^{4}$ in aqueous solution and $L$-valine, ester with 9-[(2-hydroxyethoxy) methyl] guanine hydrochloride in tablets 5 , in human serum ${ }^{6}$ to carry out drug dissolution studies. Gladys E Graneroa et al., ${ }^{7}$ has described a method for the stability of valaciclovir and implications for its oral bioavailability. A.S Jadhav et al., ${ }^{4}$ developed an enantioselective 
chiral high performance liquid chromatographic method for the enantiomeric resolution of valaciclovir. Two liquid chromatography mass spectrometry (LC-MS) methods are reported for the quantification of valaciclovir and its metabolite ${ }^{8}$ and simultaneous determination of valaciclovir and acyclovir in human plasma. Studies on electrooxidation and its square-wave and differential pulse voltammetric determination in pharmaceuticals and human biological fluids were reported by Bengi Uslua et al., ${ }^{9}$. A human valaciclovirase biphenyl hydrolaselike protein was identified as valaciclovir hydrolase by Insook Kim et al., ${ }^{10}$ which may be concluded as an important enzyme activating valaciclovir and valganciclovir in humans and an important new target for prodrug design.

The objective of this study is to develop and validate a simple and cost effective stability indicating method for rapid estimation of valaciclovir in presence of its stress degradation related impurities. Hence the proposed method can be useful as a rapid analytical technique for the degradation kinetics and to establish the degradation pathways.

\section{Experimental}

HPLC- Shimadzu Class-VP series with Class-VP Software, sonicator- Sharp Analyticals, rotary shaker- Vibramax, analytical balance- Metler Toledo, pipettes- Thermo Electron.

\section{Preparation of solutions}

\section{Preparation of mobile phase}

Acetonitrile and phosphate buffer ( $\mathrm{pH}-3.6)$ were properly mixed in the ratio of 50:50. For the preparation of phosphate buffer solution (pH-3.6), $0.9 \mathrm{~g}$ of anhydrous disodium hydrogen phosphate and $1.298 \mathrm{~g}$ of citric acid monohydrate were weighed accurately, mixed and volume made with double distilled water $(1000 \mathrm{~mL})$.

\section{Preparation of standard drug solutions}

Stock solution of valaciclovir $(1 \mathrm{mg} / \mathrm{mL})$ was prepared by dissolving $25 \mathrm{mg}$ of valaciclovir in $25 \mathrm{~mL}$ of volumetric flask containing $10 \mathrm{~mL}$ of acetonitrile and $10 \mathrm{~mL}$ of phosphate buffer (pH-3.6). The solution was sonicated for about 10 min and then made up to volume with mobile phase. Daily working standard solutions of valaciclovir was prepared by suitable dilution of the stock solution with appropriate mobile phase. Working standard solutions of valaciclovir were prepared by taking suitable aliquots of drug solution from the standard stock solution $1000 \mu \mathrm{g} / \mathrm{mL}$ and the volume was made up to $10 \mathrm{~mL}$ with mobile phase.

\section{Method development}

\section{Method optimization}

To develop a suitable and robust HPLC method for the determination of valaciclovir, different mobile phase compositions in different ratios were used at different flow rates.

\section{Method validation}

The validation parameters like linearity, sensitivity, accuracy, precision, robustness and specificity of the assay and the recovery were studied according to the US Food and drug administration (FDA) guidance for the validation of analytical methods.

Calibration curves were prepared by assaying standard sample solutions ranging from 1 to $200 \mu \mathrm{g} / \mathrm{mL}$. The linearity of each method matched calibration curve was determined by plotting the peak area $(y)$ versus the concentration $(x)$ of valaciclovir. 


\section{Assay of formulation}

Twenty tablets were weighed and finely powdered. An accurately weighed sample of powdered tablets equivalent to $25 \mathrm{mg}$ of valaciclovir was extracted with acetonitrile and phosphate buffer (pH-3.6) using ultra sonicator in a $25 \mathrm{~mL}$ volumetric flask followed by filtration through $0.45 \mu \mathrm{m}$ filter paper. The solution obtained was further diluted with the mobile phase so as to get the desired concentrations. The amount of drug present in pharmaceutical formulation was calculated by the following formula.

$$
\% \text { Assay }=\frac{\text { Sample area } \times \text { standard weight } \times \text { Average weight of } 20 \text { tablets }}{\text { Standard area } \times \text { Sample weight } \times \text { Label claim }}
$$

The limit of detection (LOD) and limit of quantitation (LOQ) were determined on the basis of response and slope of the regression equation. The precision of the method was ascertained separately from the areas under the curve obtained by actual determination of eight replicates of a fixed amount of drug and the percent relative standard deviations were calculated. The precision of the assay was also determined in terms of intra-and inter-day variation in the peak areas for a set of drug solutions on three different days. To determine the accuracy of the proposed method, recovery studies were carried out by adding different amounts $(80 \%, 100 \%$ and $120 \%)$ of bulk samples of valciclovir within the linearity ranges were taken and added to the pre-analyzed formulation of concentration $10 \mu \mathrm{g} / \mathrm{mL}$. From that percentage recovery values were calculated.

To study the robustness of the method, the test solutions were injected with deliberate variations in method parameters like flow rate, temperature, $\mathrm{pH}$ and mobile phase composition. For the ruggedness study, the prepared test solution as per the test method was analyzed by different analysts on a different instrument using the same column.

The specificity of the method was demonstrated through forced degradation studies conducted on the sample using acidic, alkaline, oxidative and photolytic degradations. The sample was exposed to these conditions and the main peak was studied for the peak purity, thus indicating that the method effectively separated the degradation products from the pure active ingredient.

\section{Results and Discussion}

\section{Chromatographic conditions}

The $\lambda_{\max }$ of valaciclovir was found to be $252 \mathrm{~nm}$. The mobile phase acetonitrile: phosphate buffer (pH-3.6) of 50:50\% v/v at a flow rate of $0.8 \mathrm{~mL} / \mathrm{min}$ gave peaks with good resolution for valaciclovir are eluted at retention time around $2.850 \mathrm{~min}$ and with symmetric peak shape.

\section{Method validation}

\section{Linearity}

When a series of dilutions were analyzed, the concentration range of 1 to $200 \mu \mathrm{g} / \mathrm{mL}$ was found to give a straight line. The linearity study is given in Figure 1 and the typical chromatogram of the pure drug is given in Figure 2.

\section{Assay of formulation}

The amount of drug present in pharmaceutical formulation was calculated to be $100.275 \%$ with SD of 0.205 and \%RSD of 0.204. A typical chromatogram of valaciclovir in formulation was shown in Figure 3 and the assay results are given in Table 1. 


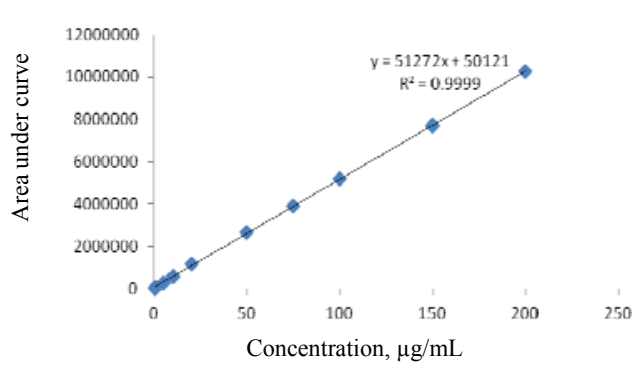

Figure 1. Linearity graph of valaciclovir

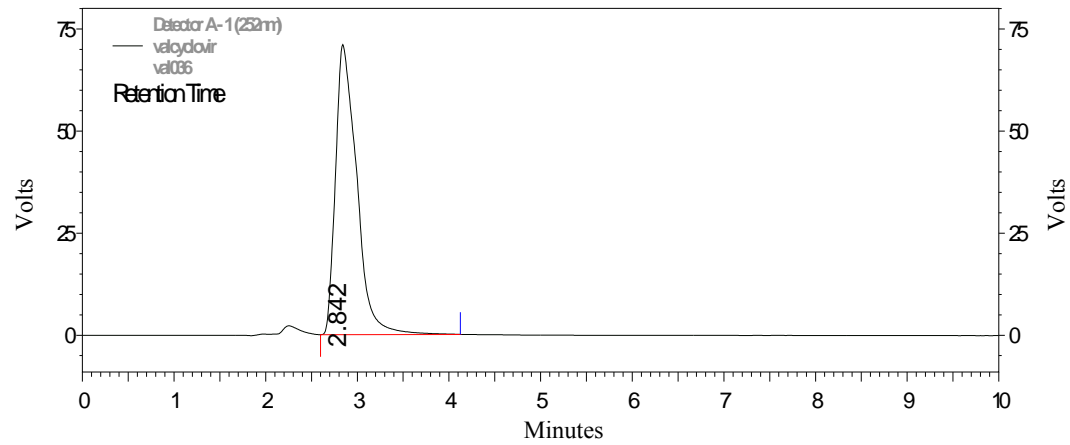

Figure 2. A Typical chromatogram of valaciclovir in pure drug $(50 \mu \mathrm{g} / \mathrm{mL})$

Table 1. Assay of formulation

\begin{tabular}{ccccc}
\hline Formulation & $\begin{array}{c}\text { Labeled } \\
\text { Amount, } \mathrm{mg}\end{array}$ & $\begin{array}{c}\text { Mean } \pm \mathrm{SD} \\
\text { (amount recovered) }\end{array}$ & \%Drug recovered & $\%$ RSD \\
\hline Valcivir (tablets) & 500 & $501.377 \pm 1.025$ & $100.275 \pm 0.205$ & 0.204 \\
\hline
\end{tabular}

${ }^{*}$ Each value is average of six determinations \pm standard deviation

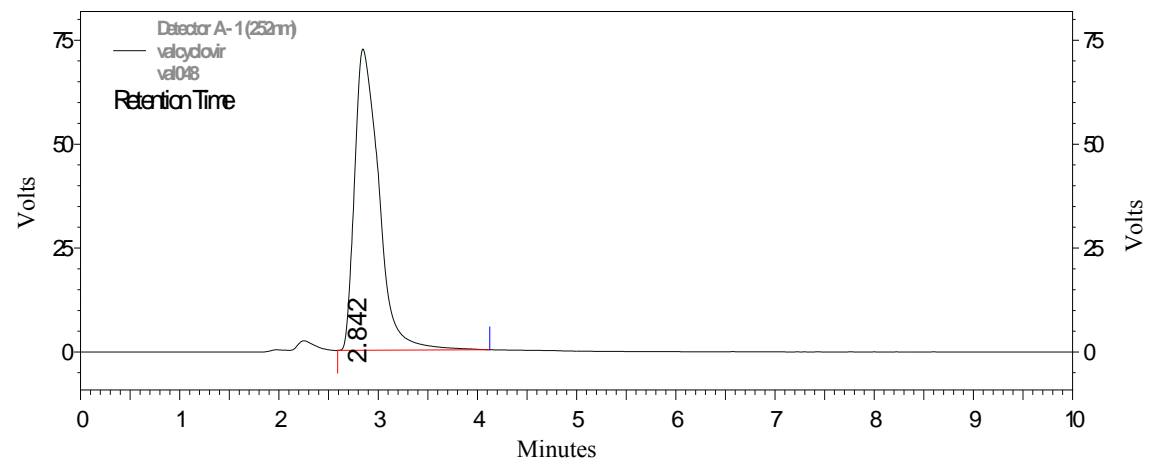

Figure 3. A Typical chromatogram of valaciclovir in formulation $(50 \mu \mathrm{g} / \mathrm{mL})$

\section{Precision and accuracy}

The method was found to be precise and the SD and \%RSD of the area under curves were calculated to be 10408.85 and 1.763 respectively and presented in the Table 2 . The accuracy of the method was determined by recovery studies and percentage recovery values were calculated. The accuracy results were shown in Table 3. 
Table 2. Precision study

\begin{tabular}{cccc}
\hline S. No. & Concentrations $\mu \mathrm{g} / \mathrm{mL}$ & AUC & Statistical analysis \\
\hline 1 & 10 & 582534 & \\
2 & 10 & 601255 & \\
3 & 10 & 596824 & Mean $=590218.5$ \\
4 & 10 & 572155 & \\
5 & 10 & 582456 & $\mathrm{SD}=10408.85$ \\
6 & 10 & 600345 & \\
7 & 10 & 589325 & $\%$ RSD $=1.76356$ \\
8 & 10 & 596854 & \\
\hline
\end{tabular}

Table 3. Accuracy study

\begin{tabular}{cccccc}
\hline \multirow{2}{*}{ Sample } & \multicolumn{2}{c}{ Concentration $\mu \mathrm{g} / \mathrm{mL}$} & $\begin{array}{c}\text { \%Recovery of } \\
\text { pure drug }\end{array}$ & \multicolumn{2}{c}{ Statistical Analysis } \\
\cline { 2 - 5 } & Pure drug & Formulation & & \\
\hline S1 $: 80 \%$ & 8 & 10 & 98.381 & Mean & 98.1337 \\
S2 $: 80 \%$ & 8 & 10 & 97.56 & SD & 0.49838 \\
S3 $: 80 \%$ & 8 & 10 & 98.46 & $\%$ RSD & 0.50786 \\
S4 $: 100 \%$ & 10 & 10 & 101.56 & Mean & 101.4633 \\
S5 $: 100 \%$ & 10 & 10 & 101.89 & SD & 0.48232 \\
S6 $: 100 \%$ & 10 & 10 & 100.94 & $\%$ RSD & 0.475365 \\
S7 $: 120 \%$ & 12 & 10 & 99.61 & Mean & 99.2533 \\
S8 $: 120 \%$ & 12 & 10 & 99.28 & SD & 0.37072 \\
S9: $120 \%$ & 12 & 10 & 98.87 & \% RSD & 0.373509 \\
\hline
\end{tabular}

\section{Limit of detection and quantitation}

The parameters LOD and LOQ for this method were found to be $0.110 \mu \mathrm{g} / \mathrm{mL}$ and $0.363 \mu \mathrm{g} / \mathrm{mL}$ respectively.

\section{Robustness}

To study the robustness of the method, the test solutions were injected with deliberate variations in method parameters like flow rate, temperature, $\mathrm{pH}$ and mobile phase composition. The reliability of the method is shown by the robustness study result given in Table 4 .

Table 4. Robustness study $(10 \mu \mathrm{g} / \mathrm{mL})$

\begin{tabular}{|c|c|c|c|c|c|}
\hline \multirow[b]{2}{*}{$\begin{array}{l}\text { Parameters } \\
\quad(\mathrm{n}=6)\end{array}$} & \multirow[b]{2}{*}{ Variables } & \multicolumn{2}{|c|}{ Statistical analysis } & \multicolumn{2}{|c|}{ Statistical analysis } \\
\hline & & $\begin{array}{c}\text { RT } \\
\text { Mean } \pm \text { SD }\end{array}$ & $\%$ RSD & $\begin{array}{l}\text { Peak area } \\
\text { Mean } \pm \text { SD }\end{array}$ & $\% \mathrm{RSD}$ \\
\hline \multirow{3}{*}{$\begin{array}{l}\text { Flow rate } \\
(\mathrm{mL} / \mathrm{min})\end{array}$} & 0.7 & $2.92 \pm 0.05$ & 1.70 & $574145 \pm 17751.79$ & 3.09 \\
\hline & 0.8 & $2.85 \pm 0.05$ & 1.75 & $582456 \pm 10408.85$ & 1.78 \\
\hline & 0.9 & $2.63 \pm 0.09$ & 3.42 & $569450 \pm 15529.48$ & 2.72 \\
\hline Mobile phase & $55: 45$ & $2.93 \pm 0.10$ & 3.41 & $582659 \pm 13499.23$ & 2.31 \\
\hline Composition & $50: 50$ & $2.85 \pm 0.05$ & 1.75 & $582456 \pm 10408.85$ & 1.78 \\
\hline \multirow[t]{2}{*}{ (Buffer : ACN) } & $45: 55$ & $2.75 \pm 0.09$ & 3.27 & $583254 \pm 18063.72$ & 3.09 \\
\hline & 26 & $2.88 \pm 0.09$ & 3.12 & $572425 \pm 11496.93$ & 2.00 \\
\hline \multirow[t]{3}{*}{ Temperature ${ }^{\circ} \mathrm{C}$} & 28 & $2.85 \pm 0.05$ & 1.75 & $582456 \pm 10408.85$ & 1.78 \\
\hline & 30 & $2.76 \pm 0.04$ & 1.44 & $583254 \pm 10373.34$ & 1.77 \\
\hline & 3.4 & $2.75 \pm 0.05$ & 1.81 & $576382 \pm 12682.56$ & 2.200 \\
\hline \multirow[t]{2}{*}{$\mathrm{pH}$} & 3.6 & $2.85 \pm 0.05$ & 1.75 & $582456 \pm 10408.85$ & 1.78 \\
\hline & 3.8 & $2.79 \pm 0.06$ & 2.15 & $586467 \pm 16632.92$ & 2.83 \\
\hline
\end{tabular}




\section{Ruggedness}

The prepared test solution as per the test method was analyzed by different analysts on a different instrument using the same column. The ruggedness study result is given in Table 5 .

Table 5. Ruggedness study

\begin{tabular}{ccccc}
\hline Variables & RT mean \pm SD & \%RSD & Peak area mean \pm SD & \%RSD \\
\hline Analyst-I & $2.75 \pm 0.05$ & 1.81 & $576382 \pm 10282.56$ & 1.20 \\
Analyst-II & $2.85 \pm 0.05$ & 1.75 & $582456 \pm 10408.85$ & 1.78 \\
\hline
\end{tabular}

\section{Forced degradation studies}

About $10 \mathrm{mg}$ of valaciclovir pure drug was accurately weighed and transferred to $10 \mathrm{~mL}$ volumetric flask which was further treated with different stress conditions and the main peak was studied for the peak purity, thus indicating that the method effectively separated the degradation products from the pure active ingredient. The summary of results of stability indicating assay is given in Table 6. From the specificity study it was found that in all types of stress conditions the drug is degrading. Furthermore Valaciclovir is more susceptible to alkaline conditions.

Table 6. Results of stability indicating assay

\begin{tabular}{|c|c|c|c|c|}
\hline Conditions applied & Peak area & $\begin{array}{l}\% \text { Drug } \\
\text { recovered }\end{array}$ & $\begin{array}{c}\text { RT of } \\
\text { analyte min }\end{array}$ & $\begin{array}{c}\text { RT of major } \\
\text { degradants min }\end{array}$ \\
\hline Standard drug (SD) & 582534 & 100.0 & 2.842 & - \\
\hline $\begin{array}{c}10 \mu \mathrm{g} \text { of SD }+1 \mathrm{~mL} \text { of } \\
0.1 \mathrm{~N} \mathrm{HCl}(1 \mathrm{~h})\end{array}$ & 573961 & 98.52833 & 2.842 & $1.967,2.258$ \\
\hline $\begin{array}{c}10 \mu \mathrm{g} \text { of SD }+1 \mathrm{~mL} \text { of } \\
0.1 \mathrm{~N} \mathrm{NaOH}(1 \mathrm{~h})\end{array}$ & 47643 & 81.78578 & 2.842 & $1.992,2.242$ \\
\hline $\begin{array}{c}10 \mu \mathrm{g} \text { of } \mathrm{SD}+1 \mathrm{~mL} \text { of } \\
3 \% \mathrm{v} / \mathrm{v} \mathrm{H}_{2} \mathrm{O}_{2}(1 \mathrm{~h})\end{array}$ & 572307 & 98.24439 & 2.842 & $1.950,2.242$ \\
\hline $\begin{array}{c}10 \mu \mathrm{g} \text { of SD solution } \\
\text { under UV }(8 \mathrm{~h})\end{array}$ & 544850 & 93.53102 & 2.842 & $1.967,2.250$ \\
\hline
\end{tabular}

\section{Acidic degradation}

About $10 \mathrm{mg}$ of valaciclovir pure drug was accurately weighed and transferred to $10 \mathrm{~mL}$ volumetric flask and $1 \mathrm{~mL}$ of $0.1 \mathrm{~N} \mathrm{HCL}$ was added and kept aside for one $\mathrm{h}$ and made up to volume with mobile phase. Then from this $10 \mu \mathrm{g} / \mathrm{mL}$ solution was prepared and injected in HPLC system to obtain chromatograms (Figure 4).

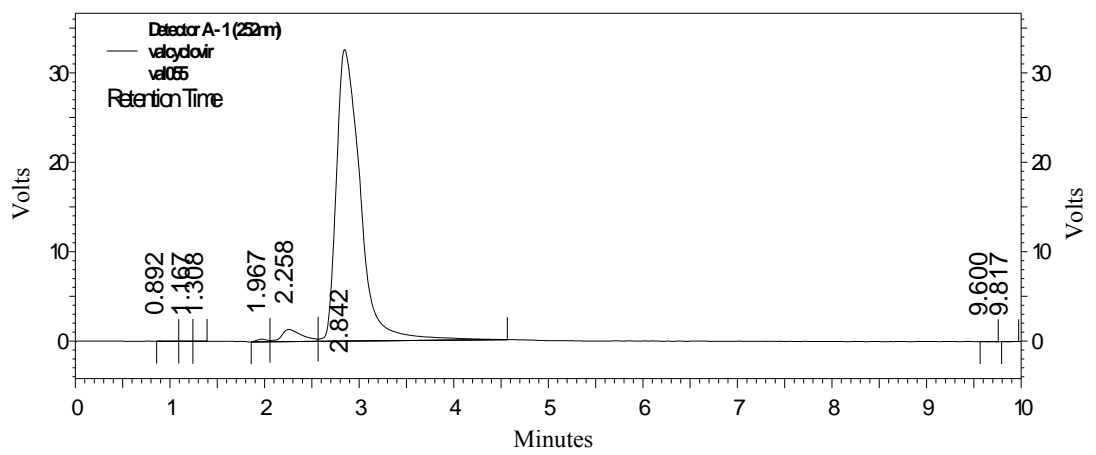

Figure 4. Chromatogram for acidic degradation 


\section{Alkaline degradation}

About $10 \mathrm{mg}$ of valaciclovir pure drug was accurately weighed and transferred to $10 \mathrm{~mL}$ volumetric flask and one $\mathrm{mL}$ of $0.1 \mathrm{~N} \mathrm{NaOH}$ was added and kept aside for one hour and made up to volume with mobile phase. Then from this $10 \mu \mathrm{g} / \mathrm{mL}$ solution was prepared and injected in HPLC system to obtain chromatograms (Figure 5).

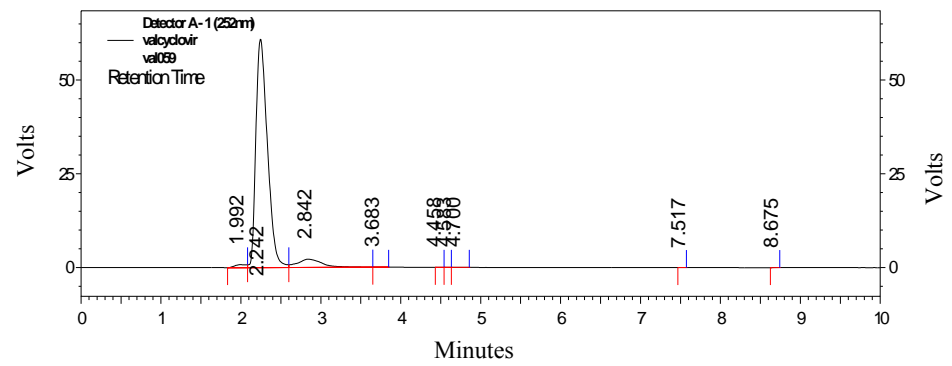

Figure 5. Chromatogram for alkaline degradation

\section{Oxidative degradation}

About $10 \mathrm{mg}$ of valaciclovir pure drug was accurately weighed and transferred to $10 \mathrm{~mL}$ volumetric flask and one $\mathrm{mL}$ of $3 \% \mathrm{w} / \mathrm{v}$ of hydrogen peroxide $\left(\mathrm{H}_{2} \mathrm{O}_{2}\right)$ was added and kept aside for two hrs and made up to volume with mobile phase. Then from this $10 \mu \mathrm{g} / \mathrm{mL}$ solution was prepared and injected in HPLC system to obtain chromatograms (Figure 6).

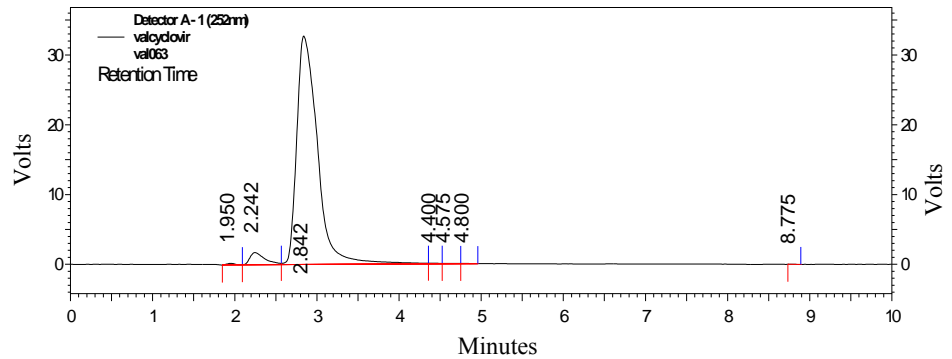

\section{Photolysis}

Figure 6. Chromatogram for oxidative degradation $\left(\mathrm{H}_{2} \mathrm{O}_{2}\right)$

About $10 \mathrm{mg}$ of valaciclovir pure drug was accurately weighed and transferred to $10 \mathrm{~mL}$ volumetric flask and made up to volume with mobile phase and kept aside for $8 \mathrm{~h}$ under direct sunlight. Then from this $10 \mu \mathrm{g} / \mathrm{mL}$ solution was prepared and injected in HPLC system to obtain chromatograms (Figure 7).

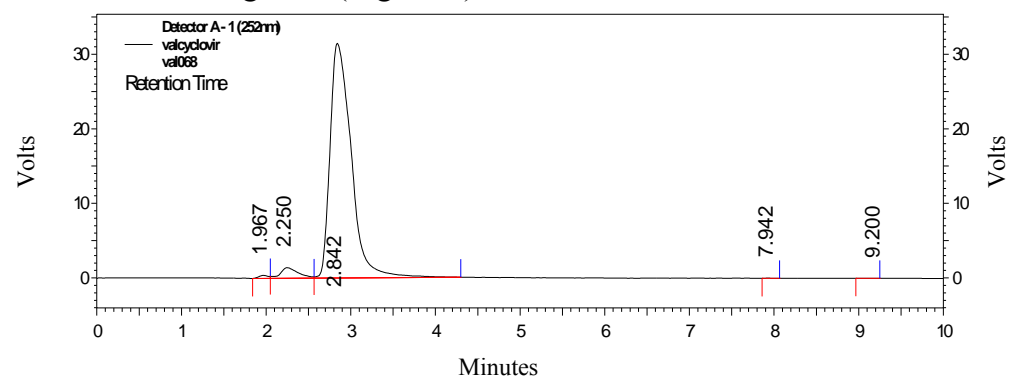

Figure 7. A Typical chromatogram for photolytic UV degradation 


\section{System suitability testing}

System suitability test of the HPLC method gave good resolution $(R=2.57)$, relative retention time $(\alpha=2.2)$, column capacity $(K=2.4)$ and tailing factor $(T=1.024)$. The system suitability parameters are given in Table 7.

Table 7. System suitability

\begin{tabular}{ccc}
\hline Parameters & Obtained value & Reference value \\
\hline Relative retention $(\alpha)$ & 2.2 & $>1$ \\
Tailing factor $(T)$ & 1.024 & $<1.5-2$ or $<2$ \\
Capacity factor $\left(K^{\prime}\right)$ & 2.4 & $1-10$ acceptable \\
Theoretical plates $(N)$ & 4369 & $>2000$ \\
Resolution $(R)$ & 2.57 & $\mathrm{R}>0.8$ \\
\hline
\end{tabular}

\section{References}

1. Ganesh M, Narasimharao C V, Saravana Kumar A, Kamalakannan K, Vinoba M, Mahajan H S and Sivakumar T, J Chem., 2009, 6(3), 814-818.

DOI:10.1155/2009/546187

2. Srinu Babu G, Sarat Babu I, Kiran kumar N, Yugandhar N M and Raju CH A I, Asian J Chem, , 2007, 19(2), 1642-1644.

3. Patil G D, Yeole P G, Manisha Puranik and Wadher S J, Int J Chem Tech Res., 2009, 1(1), 16-26.

4. Jadhav A S, Pathare D B and Shingare M S, J Pharm Biomed Anal., 2007, 43(4), 1568-1572; DOI:10.1016/j.jpba.2006.11.018

5. Palacios M L, Demasi G, Pizzorno M T and Segall A I, J Liq Chromatogr Relat Technol., 2005, 28(5), 751-762.

6. Ayhan Savaser, Cansel K. Ozkan, Yalcın Ozkan, Bengi Uslu and Sibel A Ozkan, $J$ Liq Chromatogr Relat Technol., 2003, 26(11), 1755-1767.

7. Gladys E Graneroa and Gordon L Amidonb, Int J Pharm., 2006, 317(1), 14-18; DOI:10.1016/j.ijpharm.2006.01.050

8. Maria K, Evagelos G, Sofia G, Michael K and Irene P, J Chromatogr B, 2008, 864(1-2), 78-86; DOI:10.1016/j.jchromb.2008.01.046

9. Bengi Uslua, Sibel A Özkana and Zühre Sentürkb, Anal Chim Acta, 2006, 555(2), 341-347; DOI:10.1016/j.aca.2005.09.034

10. Insook Kim, Xiao-yan Chu, Seonyoung Kim, Chester J Provoda, Kyung-Dall Lee and Gordon L Amidon, J Biol Chem., 2003, 278(28), 25348-25356;

DOI:10.1074/jbc.M302055200 